\title{
NGHIÊN CỨU VÀ ĐÁNH GIÁ TIỀM NĂNG CỦA LÁ KHÓM TRONG KÉO SỢI - DẸTT VẢI
}

\author{
NGUYỄN NGỌC XUÂN HOA ${ }^{1}$, ĐỖ NGỌC TƯỜNG QUYÊN ${ }^{2}$, HUỲNH NGUYỄN THU HÀ ${ }^{2}$ \\ ${ }^{I}$ Faculty of Garment Technology and Fashion Design, Industrial University of Ho Chi Minh City \\ ${ }^{2}$ Department of Textile - Garment Engineering, Faculty of Mechanical Engineering, Ho Chi Minh city \\ - University of Technology \\ xuanhoack06@gmail.com
}

Tóm tắt: Nguyên liệu xanh an toàn cho người sử dụng và thân thiện với môi trường đang dần trở thành xu hướng trong việc lựa chọn các sản phẩm may mặc. Bên cạnh nguồn nguyên liệu tự nhiên truyền thống như bông, lanh, len hay tơ tằm thì các xơ thực vật như gai, chuối, dứa, tre cũng đang được nghiên cứu và đưa vào sử dụng. Khóm là một loại cây lấy quả trồng khá phổ biến ở Việt Nam. Việc tận dụng lá khóm một dạng phế phẩm nông nghiệp đưa vào kéo sợi - dệt vải không chỉ khắc phục vấn đề môi trường mà còn mang lại hiệu quả kinh tế. Nội dung của nghiên cứu là tiến hành phân tách lá khóm bằng phương pháp cơ lý và hóa học từ đó đánh giá hình thái học và các thông số vật lý của xơ. Sau đó, tiến hành cắt ngắn xơ khóm, pha trộn với xơ bông và kéo sợi trên dây chuyền kéo sợi của xơ bông để đánh giá khả năng kéo sợi - dệt vải. Kết quả nghiên cứu cho thấy rằng việc phân tách xơ từ lá khóm bằng phương pháp cơ lý kết hợp với xử lý xơ trong dung dịch Sodium Hydroxide $5 \%$ ở $50^{\circ} \mathrm{C}$ trong $4 \mathrm{~h}$ thu được xơ tương đối sạch, đường kính xơ $56,17-89,36 \mu \mathrm{m}$, độ hồi ẩm của xơ $13,36 \%$, khối lượng riêng $1,44 \mathrm{~g} / \mathrm{cm}^{3}$. Sợi khóm pha bông đạt độ bền $14,5 \mathrm{cN} /$ tex cao hơn so với sợi bông $100 \%$ cùng loại là $9,3 \mathrm{cN} /$ tex và hoàn toàn có thể dệt trên máy dệt kim yêu cầu độ bền sợi $>10 \mathrm{cN} /$ tex. Tuy nhiên, nghiên cứu vẫn còn hạn chế khi xơ bị kết dính lại sau phân tách làm đường kính xơ khá lớn và không đều, sợi kéo chưa đạt độ mảnh mong muốn. Do đó, việc nghiên cứu và đưa ra phương án phân tách tối ưu cho xơ vẫn đang được tiến hành. Bên cạnh đó, việc tiền xử lý xơ được thực hiện bằng tay, năng suất thấp và mất nhiều thời gian. Để khắc phục vấn đề này thì phương án nghiên cứu chế tạo thiết bị xử lý lá sau thu hoạch cũng đang trong gian đoạn ươm mầm và hy vọng sẽ sớm hoàn thành trong thời gian sắp tới.

Từ khóa: Cây dứa (thơm, khóm), xơ dứa Việt Nam, ứng dụng của xơ dứa.

\section{STUDY AND POTENTIAL EVALUATION OF PINEAPPLE LEAF IN TEXTILE INDUSTRY}

\begin{abstract}
Safe and environmentally friendly green materials are gradually becoming a trend in choosing apparel products. In addition to traditional natural materials such as cotton, linen, wool or silk, vegetable fibers such as ramie, bananas fiber, pineapples and bamboo fiber are also being studied and used in textile industry. Pineapple is a popular fruit-growing plant in Vietnam. Taking advantage of pineapple leaves - a form of agricultural waste products into spinning - weaving not only overcome environmental problems but also brings economic efficiency. In this paper, study on splitting methods of pineapple fiber by mechanical, physical and chemical methods, thereby assessing the morphology and physical parameters of fibers. Then, refined dry pineapple fibers obtained through refined processing, which is blended with cotton to trail-produce pineapple leaf fiber/cotton (30/70) blended yarn. The results revealed that the separation of fibers from pineapple leaves by physical - mechanical method combined with fiber treatment in 5\% Sodium Hydroxide solution at $50^{\circ} \mathrm{C}$ for 4 hours obtained relatively clean fibers, fibers diameter are from 56,17 $89,36 \mu \mathrm{m}$, moisture absorption of fibers is $13,36 \%$, density is $1,44 \mathrm{~g} / \mathrm{cm}^{3}$. Durability of (30P/70C) blended yarns (at $14,5 \mathrm{cN} /$ tex) is higher than $100 \%$ cotton yarns (at 9,3 cN/tex). This blended yarn is fully wearable on knitting machines that require yarn strength $>10 \mathrm{cN} /$ tex. However, the research is still limited when the fiber is cohesive after separation, the fiber diameter is quite large and uneven. Therefore, the research on the optimal separation for fiber is still underway. In addition, pretreatment of fibers is carried out manually, low productivity and time consuming. In order to overcome this problem, the research plan to manufacture
\end{abstract}


equipment for processing post-harvest leaves is also in the germination stage and hopefully will be completed soon.

Keywords: Pineapple fiber, agricultural waste, Pineapple fiber for textile applications, Pineapple fiber production.

\section{GIỚI THIỆ}

Cùng với sự phát triển của xã hội thì các yêu cầu về thời trang cũng ngày càng thay đổi. Các chất liệu tự nhiên thân thiện với môi trường đang ngày càng được quan tâm nhiều hơn và cũng đang là xu hướng chung của thế giới và Việt Nam. Nắm bắt xu thế đó trong những năm gần đây, xơ tự nhiên đang được nghiên cứu và phát triển rất nhiều, một trong số đó là xơ dứa.

Dứa (thơm, khóm) là một loại cây thuộc họ Bromeliaceae với tên khoa học là Ananas Comosus, tên tiếng anh là Pineapples. Đây là cây ăn quả nhiệt đới có nguồn gốc ở Nam Mỹ nhưng được trồng khá phổ biến ở các quốc gia châu Á (sản lượng 60\% toàn thế giới). Theo PGS.TS Mai Thành Phụng, Trưởng Bộ phận Thường trực phía Nam - Trung tâm khuyến nông quốc gia thì ở Việt Nam, dứa được trồng khá phổ biến, phân bố từ Phú Thọ đến Kiên Giang trên diện tích khoảng 40.000 ha, với sản lượng trên 500.000 tấn/năm, $90 \%$ diện tích tập trung ở phía Nam. Hiện nay, rất nhiều giống dứa đang được trồng ở nước ta và được phân thành 3 nhóm chính là nhóm hoàng hậu (Queen), nhóm Cayen (Cayenne), nhóm dứa Tây Ban Nha (Spanish). Trong đó, nhóm dứa hoàng hậu có phẩm chất cao nhất và đang được trồng phổ biến với giống đại diện là khóm. Ở nước ta, dứa (khóm) được trồng và khai thác quả là chính, phần lá ít được chú trọng khai thác.

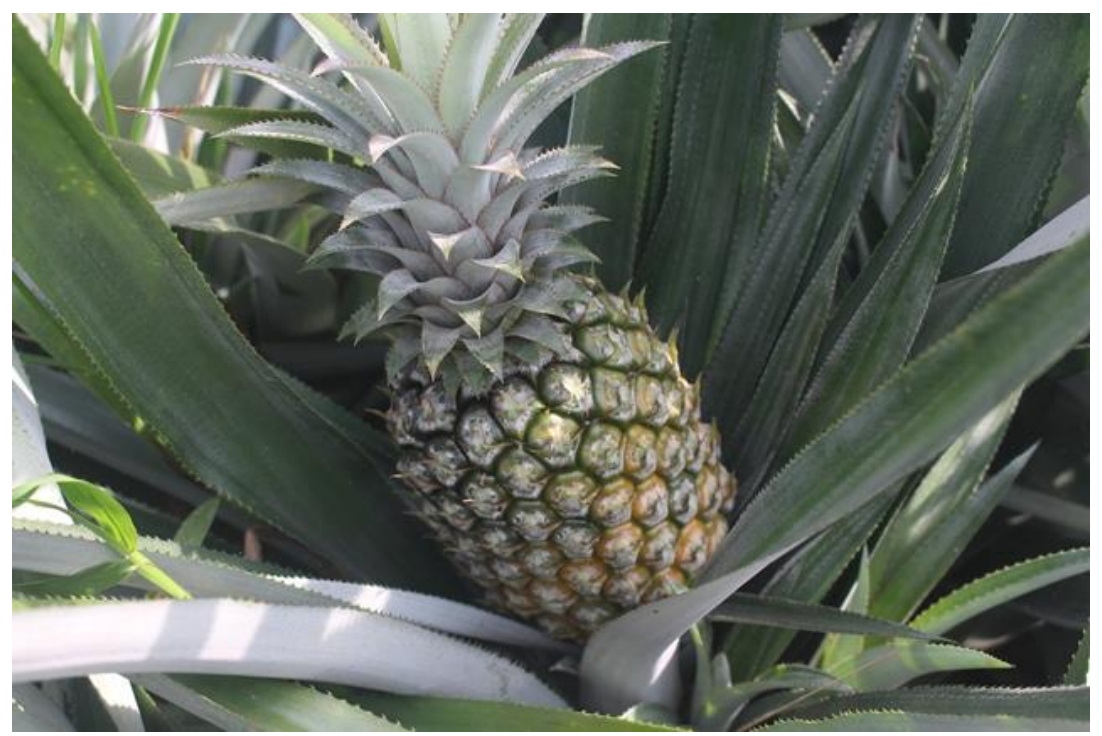

Hình 1: Dứa hoàng hậu (giống khóm)

Xơ dứa là loại xơ cellulose có nguồn gốc từ thực vật, thành phần chủ yếu là cellulose, hemi - cellulose, pectin, lignin và các vật chất khác. Trên thế giới, việc khai thác lá dứa để lấy sợi từ giống dứa (Agave sisalana) - giống dứa trồng lấy xơ đã được nghiên cứu từ rất sớm. Hai phương pháp dầm truyền thống được sử dụng để xử lý xơ dứa là dầm trong nước và dầm trong sương. Một số các phương pháp xử lý khác nhu cơ học, vật lý, hóa học hay enzyme. Đây là các phương pháp rất tiềm năng nhưng chưa được thực hiện trong quy mô công nghiệp. Với sự phát triển của công nghệ sinh học ngày nay, enzyme pectinases hoặc pectinolytic là hai loại enzyme quan trọng trong việc loại bỏ pectin ra khỏi xơ thực vật. Nó được trích tù trái cây hay tổng hợp trong phòng thí nghiệm [1].

Xử lý bằng phương pháp hóa học thì thích hợp hơn khi chúng có thể tạo ra loại xơ chất lượng mà không chịu sự ảnh hưởng của thời tiết mà thời gian xử lý ngắn. Được sử dụng trong hẩu hết các quy trình xử lý là alkali, và xử lý hóa học kiểu này giúp ta loại được hemicellulo và lignin. Chất kiềm thường được sử dụng là $\mathrm{NaOH}$, nồng độ kiềm được sử dụng vào khoảng $1-25 \%$ khối lượng [1].

Xử lý xơ dứa bằng phương pháp hoá học sử dụng $\mathrm{NaOH}$ tuy mang lại hiệu quả về thời gian xử lý nhưng làm giảm độ bền của xơ. Cụ thể khi nồng độ $\mathrm{NaOH}$ tăng và thời gian ngâm càng lâu xơ càng giảm bền [2]. Cũng xử lý xơ dứa bằng phương pháp hoá học sử dụng $\mathrm{NaOH}$ nhưng bổ sung thêm silane và điều chỉnh 
thời gian ngâm nhưng các xơ tạo nên từ nghiên cứu này không đáp ứng được điều kiện kéo sợi [3]. Theo [2] và [3], các xơ phân tách từ lá dứa đều sử dụng cho vật liệu composite do không đảm bảo các thông số cơ lý cần thiết cho kéo sợi. Cũng nghiên cứu về phân tách xơ dứa (Sisal), nhưng Pinkie $\mathrm{E}$. Zwane và Rinn M. Cloud (2006) [4] không nghiên cứu trong ứng dụng vật liệu composite mà là trong vải. Mặc dù chưa mang lại hiệu quả do xơ phân tách còn thô và chưa đạt độ đồng đều nhưng phần nào cho thấy tiềm năng của xơ dứa (sisal) trong ngành dệt may.

Trong những năm gần đây, việc phân tách lá dứa (khóm) từ giống dứa trồng lấy quả (pineapples) bắt đầu được quan tâm nghiên cứu. Bằng phương pháp hoá học sử dụng $\mathrm{NaOH}$, các xơ sau xử lý được sử dụng cho vật liệu commposite [5], [6], [7]. Để có thể sử dụng xơ khóm cho các ứng dụng may mặc, đòi hỏi xơ sau phân tách phải có độ mảnh, độ đều và các thông số cơ lý phù hợp cho kéo sợi. Yusri Yusof và ctg. (2015) [8] đã tiến hành nghiên cứu các giải pháp phân tách xơ khóm. Kết quả của nghiên cứu này bước đầu phân tách được xơ khóm giúp giải quyết được lượng chất thải nông nghiệp và tăng tính kinh tế cho quá trình canh tác khóm. Ở Việt Nam, một số nhà nghiên cứu cũng bắt đầu quan tâm đến lá của loại dứa trồng lấy quả này, cụ thể là Nguyễn Hữu Niếu và ctg. (2007) [9] đã nghiên cứu ảnh hưởng của hydroxide sodium đến các tính chất của sợi dứa Việt Nam (sợi khóm) nhằm sử dụng sợi dứa đã được xử lý để chế tạo vật liệu composite nền nhựa polyolefin.

Khóm là loại trái cây bổ dưỡng, chất Bromelin được chiết từ dứa có đặc tính kháng phù và kháng viêm, được sử dụng để làm thuốc tẩy giun, làm liền sẹo, giảm đau nhức do hư khớp ... Nếu có thể tận dụng lá khóm - nguồn phế thải nông nghiệp ứng dụng trong kéo sợi - dệt vải sẽ giúp tăng giá trị của cây khóm, giúp việc trồng khóm mang lại hiệu quả kinh tế cao và giảm thiểu đáng kể lượng chất thải nông nghiệp này vào môi trường. Như vậy, việc nghiên cứu đánh giá tiềm năng của khóm cho ứng dụng dệt may là rất cần thiết và nên được quan tâm nghiên cứu.

\section{NGUYÊN LIỆU VÀ PHƯƠNG PHÁP NGHIÊN CÚU}

\subsection{Nguyên liệu}

Lá dứa (khóm): loại lá được chọn thuộc nhóm dứa hoàng hậu (giống khóm), bản lá hẹp, cứng và có gai ở mép lá được lấy từ cánh đồng khóm của hộ dân ở Bà Rịa - Vũng Tàu.

Xơ bông: dùng pha trộn với xơ khóm để thử nghiệm khả năng kéo sợi. Loại bông NAZI xuất xứ Tây Phi, với chiều dài xơ $11 / 8 ",(28,6 \mathrm{~mm})$.

Hoá chất: $\mathrm{NaOH}$ độ tinh khiết $\geq 99 \%$ và $\mathrm{CH}_{3} \mathrm{COOH}$ độ tinh khiết $\geq 30 \%$, Glycerin độ tinh khiết $\geq 99,7 \%$, xuất xứ từ Trung Quốc.

\subsection{Phương pháp phân tách xơ khóm}

\subsubsection{Giai đoạn tiền xủ lý}

Lá khóm sau khi cắt được rửa sạch, phơi héo. Sau đó dùng mảnh sứ cạo sạch phần thịt lá để tách xơ khỏi lá. Xơ thu được sẽ đem ngâm rửa ở nhiệt độ khoảng $50^{\circ} \mathrm{C}$ loại phần thịt lá còn sót lại. Sau cùng xơ sẽ được đem phơi khô và lưu lại chuẩn bị cho quá trình xử lý tiếp theo.

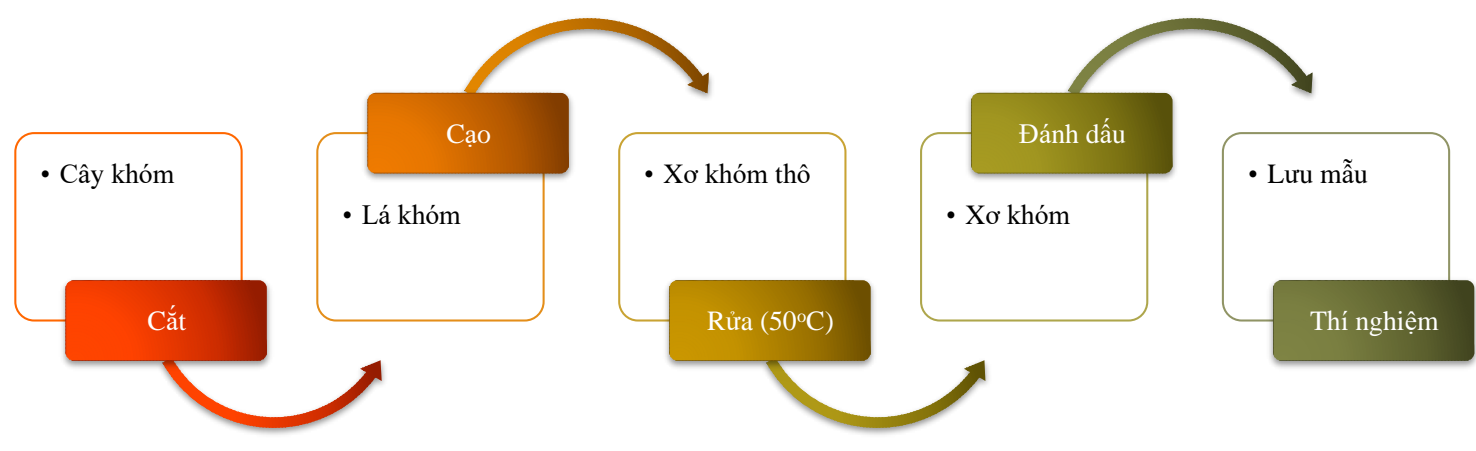

Hình 2: Quy trình tiền xủ lý xo khóm 

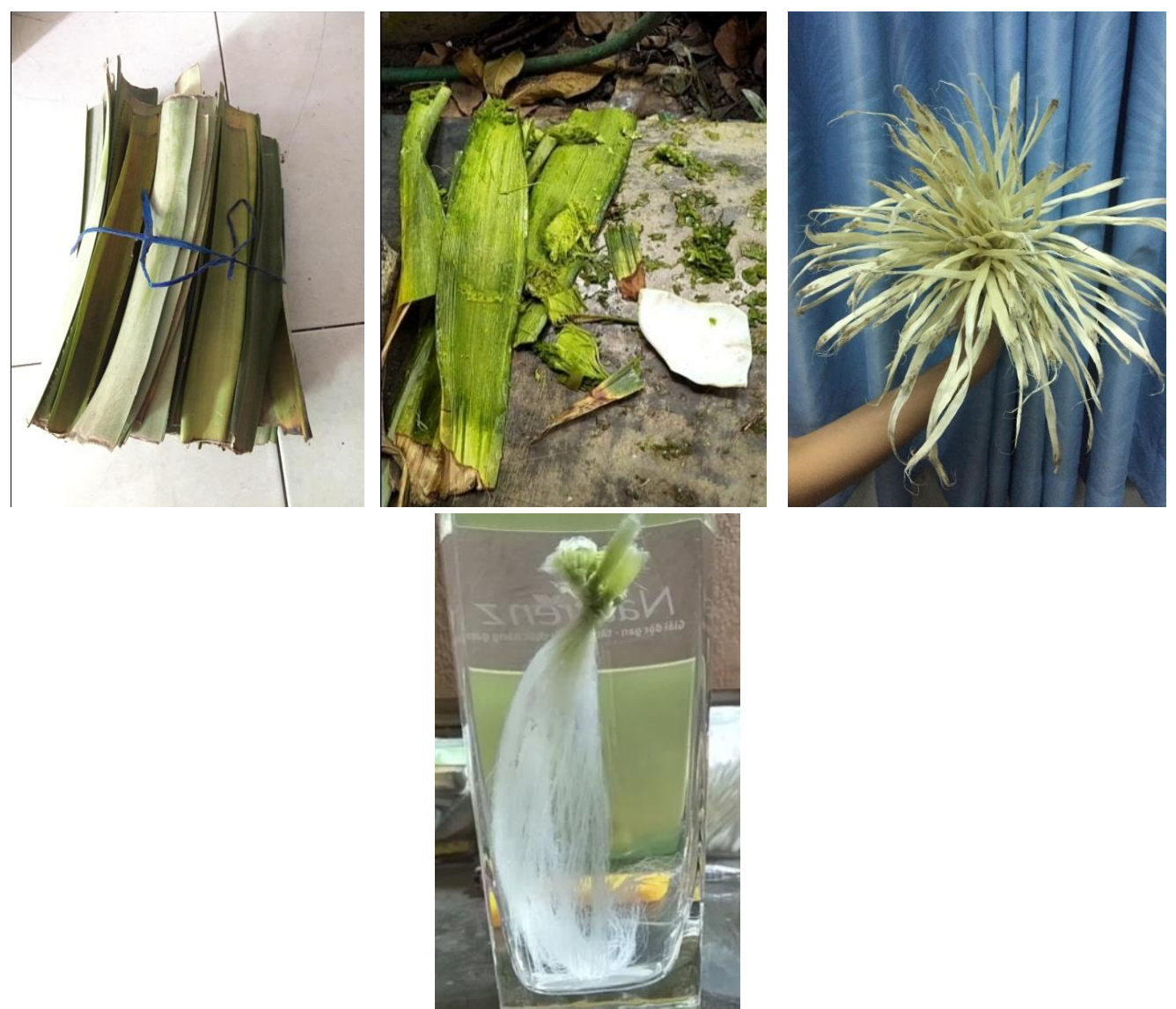

\subsubsection{Xủ lý xo trong trong dung dịch Sodium Hydroxide}

Mẫu xơ khóm sau giai đoạn tiền xử lý sẽ được đem ngâm trong dung dịch Sodium Hydroxide $5 \%$ ở $50^{\circ} \mathrm{C}$ trong 4 giờ, sau đó được rửa sạch trong nước nhiều lần để loại bỏ $\mathrm{NaOH}$ còn sót lại. Mẫu xơ tiếp tục đem ngâm trong dung dịch $\mathrm{CH}_{3} \mathrm{COOH} 1 \%$ trong 1 giờ để trung hòa lượng xút còn lưu lại bên trong xơ. Sau đó xơ tiếp tục đem đi rửa sạch và ngâm trong dung dịch Glycerin $40^{\circ} \mathrm{C}$ trong 1 giờ để tạo ẩm cho xơ và giúp xơ mềm hơn. Sau cùng xơ sẽ được phơi khô tự nhiên, kết hợp với chải để hỗ trợ cho quá trình phân tách xơ. Xơ sau xử lý sẽ được bảo quản trong túi nhựa polyethylene kín và lưu trữ trong phòng thí nghiệm.

\subsection{Phương pháp đánh giá chất lượng xơ sau xử lý}

Xơ sau khi xử lý sẽ được đánh giá hình thái học, bề mặt xơ, quan sát mặt cắt ngang và đo đường kính của xơ thông qua ảnh chụp bằng kính hiển vi điện tử quét SEM ở Trung tâm công nghệ sinh học TP Hồ Chí Minh.

\subsection{Phương pháp xác định khối lượng riêng}

Mẫu xơ sau xử lý sẽ được xác định khối lượng riêng bằng phương pháp bình tỷ trọng theo tiêu chuẩn ASTM C128 - 88. Thực hiện thí nghiệm 5 lần, tiến hành đánh giá độ tin cậy của kết quả bằng cách tính độ lặp lại $\mathrm{r}$. So sánh khối lượng riêng của xơ khóm với các xơ tự nhiên khác.

\subsection{Phương pháp xác định độ hồi ẩm}

Mẫu xơ sau xử lý sẽ được đem sấy khô đến khối lượng không đổi. Cho xơ vào máy đo độ hồi ẩm để xác định giá trị. Tiến hành thí nghiệm 5 lần, đánh giá kết quả trung bình bằng cách tính độ lặp lại $r$ để xác định mức độ tin cậy của kết quả.

\subsection{Phương pháp kéo sợi xơ khóm pha bông, sợi bông $100 \%$ và xác định độ bền kéo đứt của sọ̣i}

Xơ khóm sau phân tách sẽ được cắt ngắn với chiều dài tương đương xơ bông NAZI của công ty dệt 28 , sau đó trộn đều với xơ bông theo tỷ lệ $\mathrm{P} 30 / \mathrm{C} 70$ và $\mathrm{P} 50 / \mathrm{C} 50$. Tiến hành kéo sợi trên dây chuyền kéo sợi bông của công ty Brotex. Kéo sợi $100 \%$ bông trong cùng điều kiện.

Sợi xơ khóm pha bông và sợi $100 \%$ bông sẽ được đem thử độ bền kéo đứt trên máy đo độ bền kéo đứt sợi tại công ty Brotex. 
So sánh độ bền kéo đứt sợi xơ dứa pha bông với sợi bông $100 \%$ và độ bền của sợi dệt kim tiêu chuẩn để đánh giá khả năng tạo vải của sợi thu được.

\section{KÊT QUẢ NGHIÊN CÚU}

\subsection{Hình thái học, bề mặt xơ khóm sau xử lý}

Xơ khóm là một loại xơ cellulose thực vật được tạo nên từ các tế bào thực vật có thành phần chủ yếu là cellulose. Các tế bào thực vật này sẽ phát triển thành các xơ đơn và liên kết với nhau thành những mô sợi hay mô libe bằng các chất kết dính như Pectin, Lignin, ... Quá trình phân tách, xử lý lá khóm trong bài báo nhằm phân tách các mô libe này thành các xơ dài gọi là xơ kĩ thuật, tạo nên từ một số xơ cơ bản ghép lại với nhau.

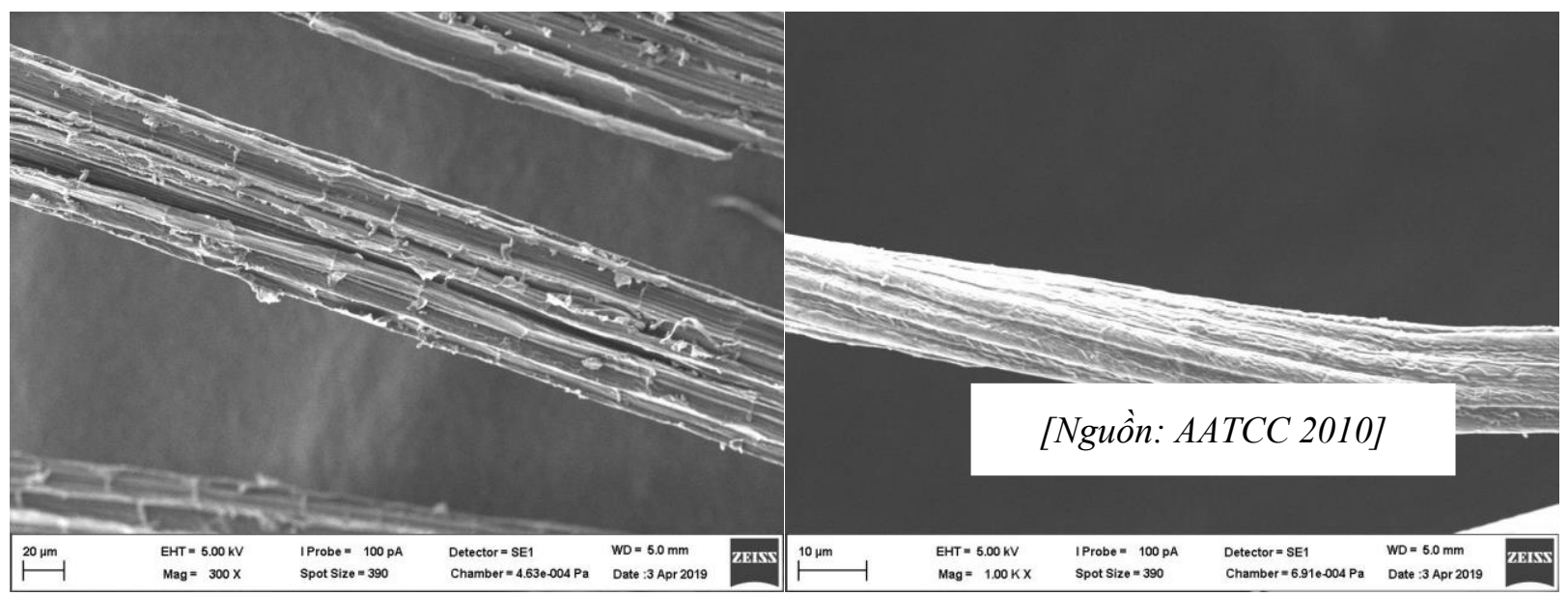

Hìn 3: Anh SEM của xo thô

Hìn 4: Anh SEM xo khóm đã xủ lý

Quan sát ảnh chụp SEM của xơ thô (xơ tiền xử lý) và xơ đã trải qua quá trình xử lý với $\mathrm{NaOH}$ ta thấy rằng đối với xơ thô, bề mặt xơ có các rãnh chạy dài suốt chiều dài xơ, trên bề mặt vẫn còn nhiều tạp chất của phần thịt lá còn lưu lại sau công đoạn cạo xơ và một phần lớp keo liên kết các xơ cơ bản bị bong ra do ma sát trong quá trình cạo lá. Đối với mẫu xơ khóm đã xử lý với $\mathrm{NaOH}$ thì trên thân xơ vẫn thấy rãnh chạy theo chiều dài xơ nhưng các rãnh này không sâu và rõ như xơ thô. Ngoài ra bề mặt xơ tương đối sạch và không còn phần thịt lá hay lớp keo liên kết các tế bào thực vật. Điều này cho thấy phương án xử lý xơ với $\mathrm{NaOH}$ mang lại hiệu quả bước đầu về mặt hình thái xơ.

\subsection{Biên dạng mặt cắt ngang của $x 0^{\prime}$}

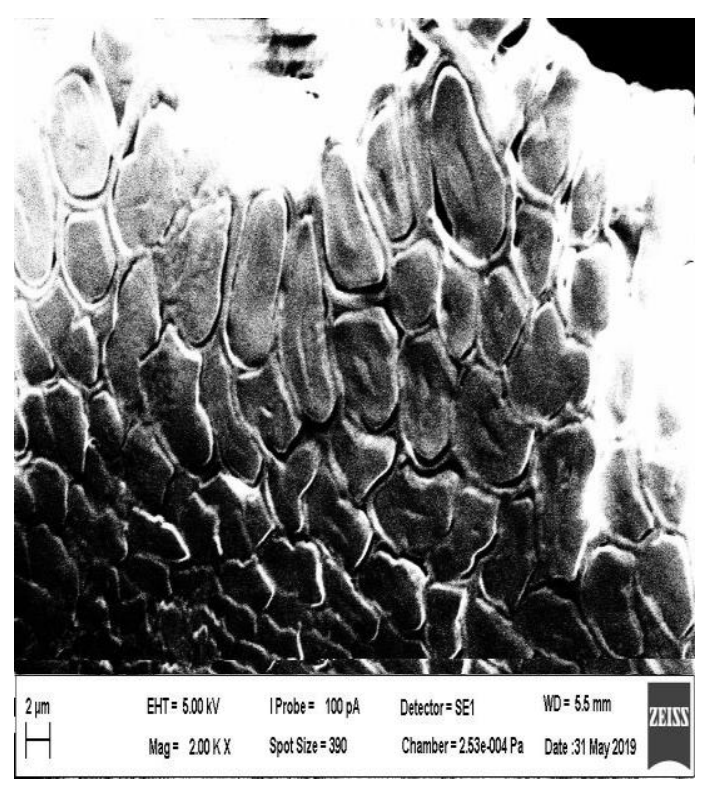

Hình 5: Anh SEM mặt cắt ngang xo khóm

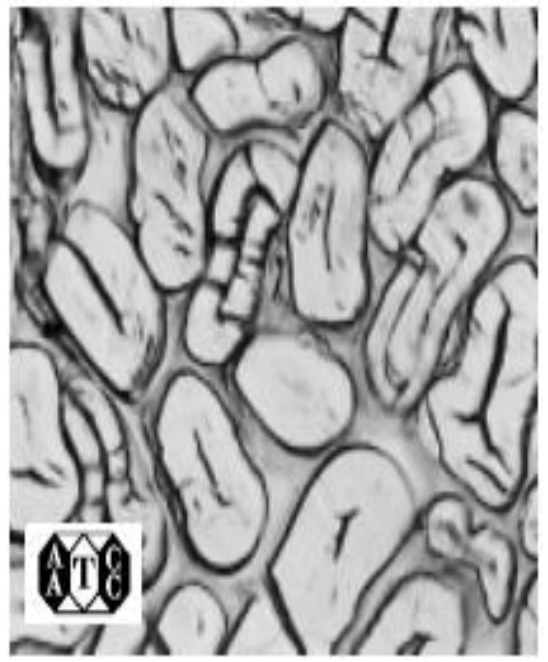

Hình 6: Anh SEM mặt cắt ngang xo Gai 
Xơ khóm sau xử lý tiến hành chụp SEM mặt cắt ngang với độ phóng đại 2 triệu lần và đo đường kính xơ đơn. Kết quả cho thấy biên dạng của xơ khóm đơn là hình dẹt (tương tự với biên dạng của xơ gai - Hình 6), ở giữa xơ đơn có rãnh - rãnh này là lumen của xơ. Đường kính của xơ khóm đơn vào khoảng $5-6 \mu \mathrm{m}$ nhỏ hơn so với đường kính xơ bông $(12-25 \mu \mathrm{m})$.

\section{3. Đường kính xơ sau xử lý}

Các mẫu xơ trong quá trình chụp trên kính hiển vi điện tử quét SEM đã được tiến hành đo đường kính và đưa ra được khoảng dao động đường kính trong các mẫu. Kết quả cho thấy khi đo đường kính ngẫu nhiên của một số xơ đã xử lý thì đường kính dao động trong khoảng $56,17-89,36 \mu \mathrm{m}$. Kết hợp giữa đường kính xơ kỹ thuật và đường kính xơ đơn đo được ở hình ảnh chụp mặt cắt ngang thì mỗi xơ khóm chứa $10-18$ xơ đơn. Như vậy, đường kính xơ sau phân tách vẫn còn khá lớn, số lượng xơ đơn liên kết với nhau còn khá nhiều và khoảng dao động của đường kính cũng khá rộng. Điều này cho thấy độ mảnh cũng như độ đồng đều của các xơ vẫn chưa tối ưu và cần tiếp tục được nghiên cứu xử lý.

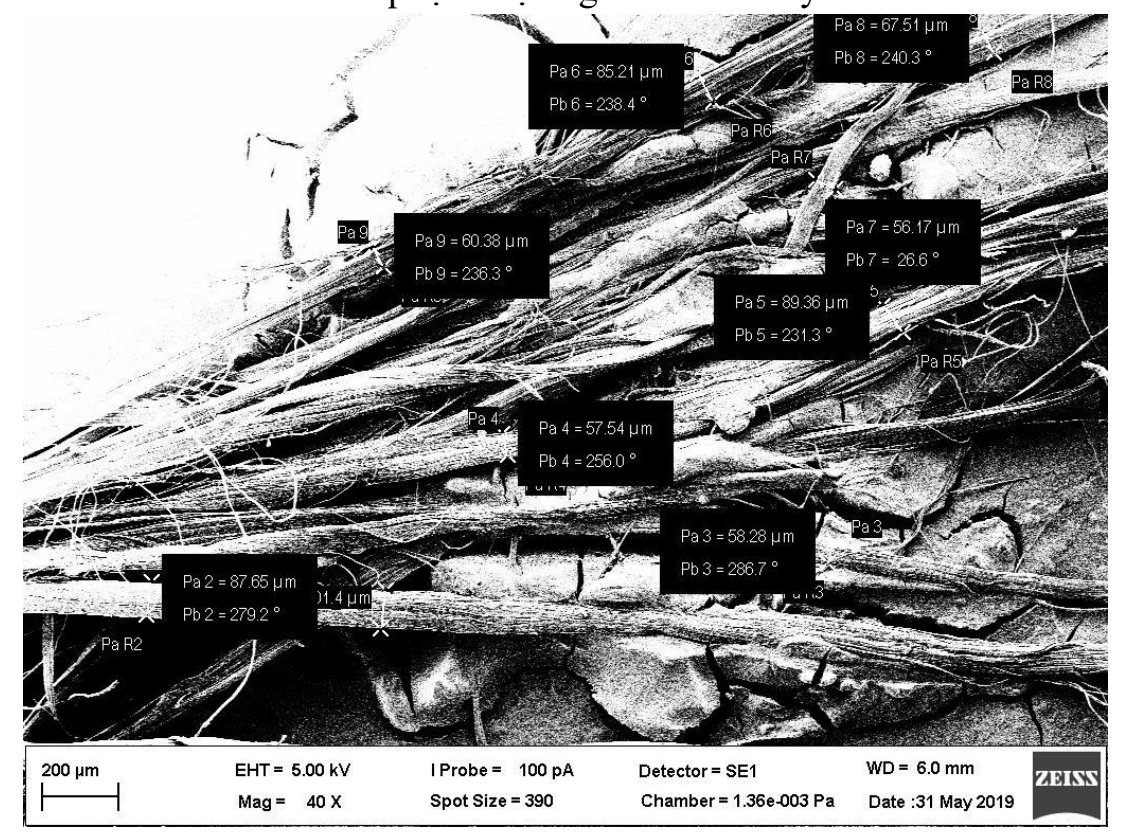

Hình 7: Đuò̀ng kính xơ sau xủ lý

\subsection{Khối lượng riêng của xơ khóm}

Khối lượng riêng của xơ khóm sau 5 lần xử lý và đánh giá độ tin cậy của kết quả bằng cách tính độ lặp lại $\mathrm{r}$ với mức chắc chắn là $95 \%$ thì khối lượng riêng của xơ khóm là trung bình của 5 lần thí nghiệm như bảng bên dưới:

\begin{tabular}{|c|c|c|c|c|c|}
\hline & 1 & 2 & 3 & 4 & 5 \\
\hline $\mathbf{m}_{\mathbf{b}}$ & 120,94 & 112,06 & 102,9 & 115,65 & 114,56 \\
\hline $\mathbf{m}_{b+\mathbf{x}}$ & 133,71 & 125,43 & 119,63 & 130,49 & 128,46 \\
\hline $\mathbf{m}_{1}$ & 310,75 & 313,03 & 308,32 & 306,1 & 303,61 \\
\hline $\mathbf{m}_{2}$ & 315,23 & 316,46 & 312,41 & 310,1 & 309 \\
\hline$\gamma_{\mathrm{R}}$ & 1,54 & 1,35 & 1,32 & 1,37 & 1,63 \\
\hline \multicolumn{6}{|c|}{ Trọng lượng riêng trung bình $1,44 \mathrm{~g} / \mathrm{cm}^{3}$} \\
\hline \multicolumn{6}{|c|}{ Độ lệch chuẩn s =0,137 } \\
\hline
\end{tabular}

Khối lượng riêng của các xơ tự nhiên và xơ nhân tạo phổ biến trong may mặc như bảng bên dưới: Bảng 2: Khối luọng riêng của của một vài loại xơ sội thông dụng của ngành dệt may [10] 


\begin{tabular}{|l|c|c|}
\hline \multirow{2}{*}{ Xơ, sợi } & \multicolumn{2}{|c|}{ Khối lượng riêng $\left[\mathrm{g} / \mathrm{cm}^{3}\right]$} \\
\cline { 2 - 3 } & Khô & $65 \% \mathrm{RH}$ \\
\hline Bông & 1,55 & 1,52 \\
\hline Viscose & 1,52 & 1,49 \\
\hline Tơ tằm & 1,34 & 1,34 \\
\hline Acetate, triacetate & 1,31 & 1,32 \\
\hline Len & 1,3 & 1,32 \\
\hline
\end{tabular}

Quan sát biểu đồ so sánh khối lượng riêng của xơ khóm với các loại xơ khác trong may mặc thì thấy rằng khối lượng riêng của xơ khóm là $1,44 \mathrm{~g} / \mathrm{cm}^{3}$ thấp hơn so với các xơ có nguồn gốc cellulose khác như bông $\left(1,55 \mathrm{~g} / \mathrm{cm}^{3}\right)$ và vicose $\left(1,52 \mathrm{~g} / \mathrm{cm}^{3}\right)$, nhưng cao hơn so với xơ acetate $\left(1,31 \mathrm{~g} / \mathrm{cm}^{3}\right)$ và xơ protein cụ thể là tơ tằm $\left(1,34 \mathrm{~g} / \mathrm{cm}^{3}\right)$ và len $\left(1,3 \mathrm{~g} / \mathrm{cm}^{3}\right)$. Như vậy, nếu xơ khóm có khả năng tạo vải thì so với vải bông và vải viscose dệt cùng thông số sợi và cấu trúc thì vải từ xơ khóm sẽ nhẹ hơn. Điều này cho thấy được tiềm năng của xơ khóm trong dệt may khi tạo cảm giác nhẹ nhàng cho người mặc so với các vải cellulose khác.

Biểu đồ 1: Biểu đồ so sánh khối lượng riêng của xo khóm vói các loại xo khác

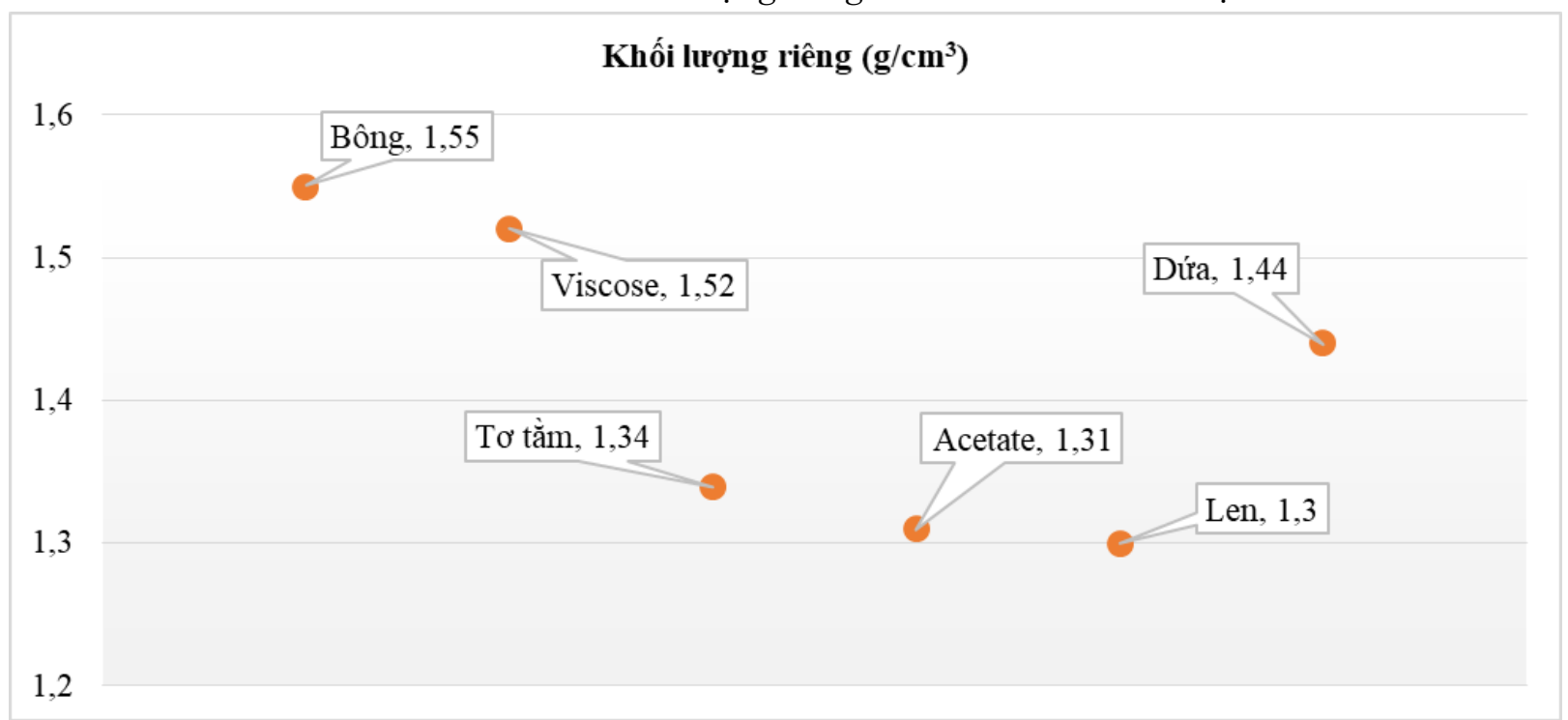

\section{5. Đánh giá độ hồi ẩm của xơ khóm}

Độ hồi ẩm của xơ khóm sau 5 lần xử lý và đánh giá độ tin cậy của kết quả bằng cách tính độ lặp lại $\mathrm{r}$ với mức chắc chắn là $95 \%$ thì độ hồi ẩm của xơ khóm là trung bình của 5 lần thí nghiệm như bảng bên dưới:

Bảng 3: Độ hồi ẩm của xo khóm

\begin{tabular}{|c|c|c|c|c|}
\hline STT & Nhiệt độ sấy $\left({ }^{\mathbf{0}} \mathbf{C}\right)$ & Thời gian sấy (phút) & Khối lượng xo (g) & Độ hồi ẩm (\%) \\
\hline $\mathbf{1}$ & 105 & 5,1 & 0,115 & 14,78 \\
\hline $\mathbf{2}$ & 105 & 3,7 & 0,321 & 13,27 \\
\hline $\mathbf{3}$ & 105 & 8,5 & 0,143 & 12,23 \\
\hline $\mathbf{4}$ & 105 & 2,3 & 0,352 & 11,42 \\
\hline $\mathbf{5}$ & 105 & 3,1 & 0,22 & 15,11 \\
\hline \\
Độ hồi ẩm trung bình 13,36 \\
\hline Độ lệch chuẩn $\mathrm{s}=1,59$
\end{tabular}

Độ hồi ẩm của các xơ tự nhiên phổ biến trong lĩnh vực dệt may như bên dưới: 
Bảng 5: Độ ẩm quy định của xo sợi thông dụng theo tiêu chuẩn Hoa Kỳ [10]

\begin{tabular}{|l|c|l|c|}
\hline \multicolumn{1}{|c|}{ Tên xơ sợi } & $\begin{array}{c}\text { Độ ẩm theo ASTMD 1909 } \\
\text { Wq [\%] }\end{array}$ & \multicolumn{1}{|c|}{ Tên xơ sợi } & $\begin{array}{c}\text { Độ ẩm theo ASTMD } \\
1909 \text { Wq [\%] }\end{array}$ \\
\hline Xơ bông Ai Cập & 8,5 & Đay & 13,75 \\
\hline Xơ lanh & 12 & Len & 13,6 \\
\hline Gai & 7,6 & Tơ tằm & 11 \\
\hline
\end{tabular}

Quan sát biểu đồ so sánh độ ẩm của xơ khóm với các xơ tự nhiên khác thì thấy rằng trong nhóm xơ tự nhiên gốc cellulose thì độ độ ẩm của xơ khóm 13,36 \% là khá tốt chỉ kém hơn đay $(13,75 \%)$ - một loại xơ ít dùng trong may mặc nhưng lại cao hơn so với các xơ cellulose khác như xơ lanh (12\%), xơ bông $(8,5 \%)$ và gai $(7,6 \%)$. Đối với nhóm xơ tự nhiên gốc protein như len, tơ tằm thì độ ẩm của khóm cao hơn. Như vậy, nếu xơ khóm có khả năng tạo vải thì so với các loại vải tự nhiên gốc cellulose lẫn protein dệt cùng thông số sợi và cấu trúc thì vải từ xơ khóm sẽ cho khả năng hút ẩm tốt hơn, tạo cảm giác thoải mái cho người mặc hơn trừ vải đay. Điều này cho thấy tiềm năng của xơ khóm khi tạo sản phẩm có tính tiện nghi cao.

Biểu đồ 2: Biểu đồ so sánh độ ẩm của xơ khóm với các xo tụ nhiên khác

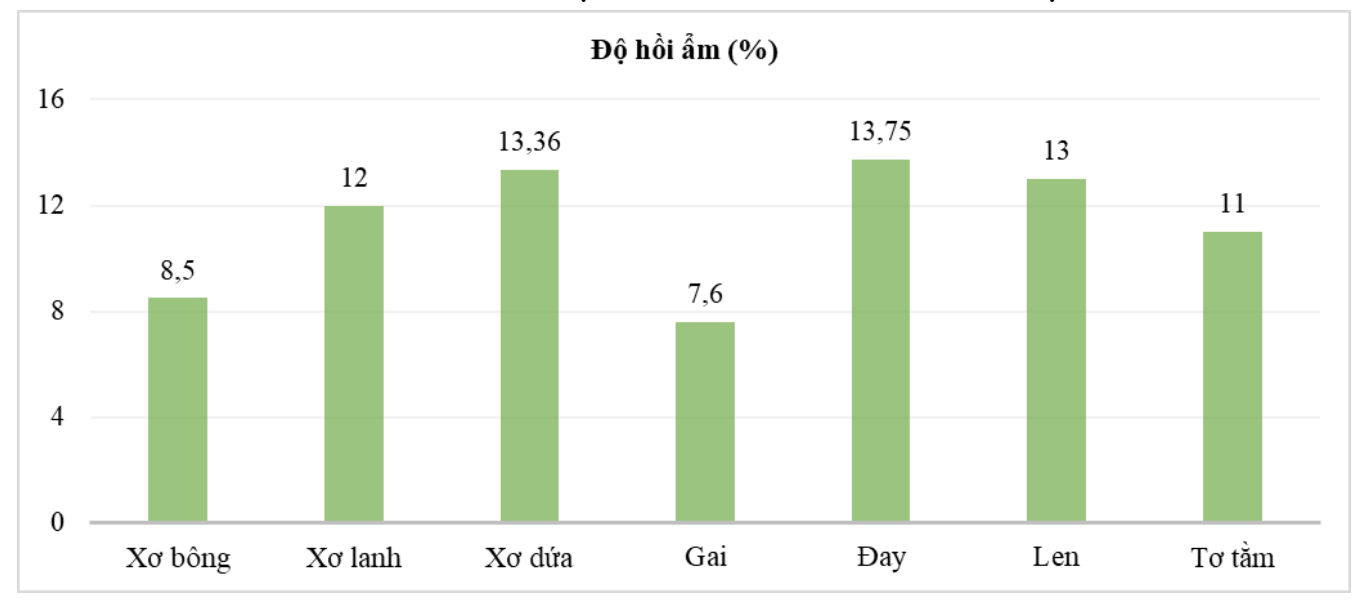

\section{6. Đánh giá khả năng kéo sợi - dệt vải của xơ khóm}

Xơ khóm là một loại xơ khá mới ở Việt Nam và chưa có dây chuyền kéo sợi chuyên biệt. Vì vậy để đánh giá khả năng kéo sợi - dệt vải của xơ khóm trong nghiên cứu này sẽ tiến hành pha trộn xơ khóm với xơ bông và sẽ được kéo sợi trên dây chuyền kéo sợi của bông. Bên cạnh đó, để đánh giá được tiềm năng của xơ khóm trong dệt may thì nghiên cứu này còn tiến hành kéo sợi $100 \%$ xơ bông trong cùng điều kiện để đánh giá độ bền của xơ khóm khi tạo sợi so với sợi bông $100 \%$ và kết quả được thể hiện trong biểu đồ bên dưới:

Biểu đồ 3: Biểu đồ so sánh độ bền của sọi bông 100\%, sọi khóm pha 30P/70C và sọi khóm pha 50P/50C

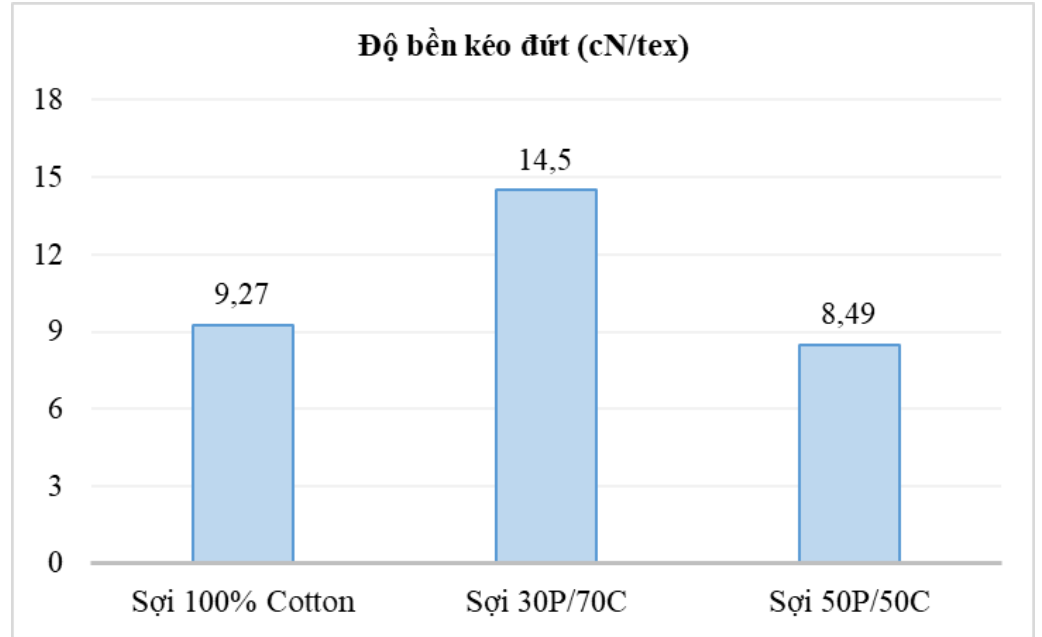

Quan sát biểu đồ trên ta thấy rằng, khi pha trộn tỷ lệ xơ dứa và xơ bông phù hợp thì sợi tạo nên sẽ cho độ bền tốt hơn so với sợi $100 \%$ bông. Cụ thể sợi pha trộn giữa xơ khóm và xơ bông theo tỷ lệ $30 / 70$ cho độ 
bền là $14,5 \mathrm{cN} /$ tex cao hơn so với sợi bông $100 \%$ là 9,27 cN/tex. Điều này cho thấy xơ khóm hoàn toàn có khả năng ứng dụng trong kéo sợi.

Ngoài ra để đánh giá khả năng dệt vải của loại sợi khóm pha bông, trong giới hạn của bài nghiên cứu chỉ đánh giá khả năng dệt kim của loại sợi này, tiển hành so sánh độ bền kéo đứt của sợi này với sợi tiêu chuẩn cho dệt kim. Kết quả cho thấy với độ bền kéo đứt của sợi khóm pha là $14,5 \mathrm{cN} /$ tex cao hơn yêu cầu tiêu chuẩn về độ bền của sợi dệt kim là $>10 \mathrm{cN} /$ tex. Do đó, về mặt lý thuyết sợi hoàn toàn có thể dệt kim. Tiến hành dệt thử mẫu vải trên máy dệt kim thí nghiệm và được sản phẩm như hình bên dưới.

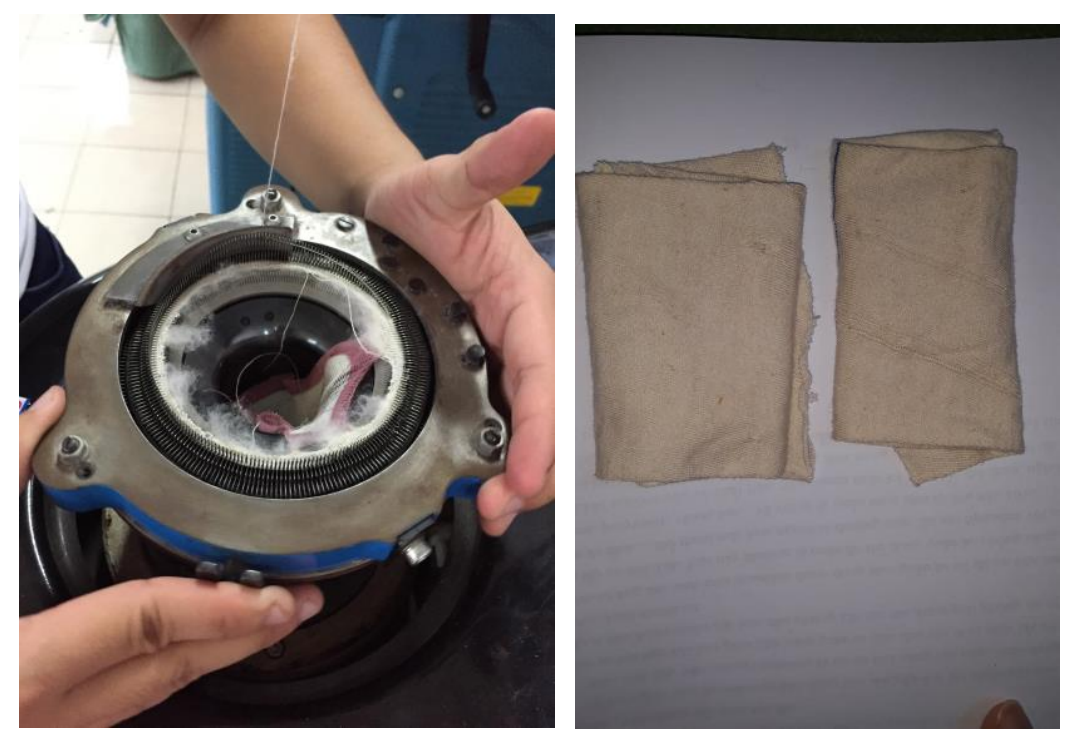

Hìn 8: Sọi khóm dệt trên máy dệt kim

\section{KẾT LUẬN}

Bài nghiên cứu đã cho thấy tiềm năng của xơ khóm trong kéo sợi - dệt vải. Kết quả nghiên cứu cho thấy rằng việc phân tách xơ từ lá khóm bằng phương pháp cơ lý kết hợp với xử lý xơ trong dung dịch Sodium Hydroxide $5 \%$ ở $50^{\circ} \mathrm{C}$ trong $4 \mathrm{~h}$ thu được xơ tương đối sạch, đường kính xơ sau khi phân tách vào khoảng $56,17-89,36 \mu \mathrm{m}$, tiết diện mặt cắt ngang xơ hình dẹt với đường kính đo được vào khoảng $5-6 \mu \mathrm{m}$, bề mặt xơ sau phân tách hầu như không còn vết tạp.

Thực hiện kiểm tra một số thông số xơ khóm và so sánh với các xơ khác. Kết quả cho thấy xơ khóm có trọng lượng riêng là $1,44 \mathrm{~g} / \mathrm{cm}^{3}$ thấp hơn xơ bông và cao hơn tơ tằm và len, độ hồi ẩm xơ thơm là $13,36 \%$ tương đương xơ đay và len.

Thử nghiệm kéo sợi khóm pha bông trên dây chuyền kéo sợi xơ bông và so sánh độ bền kéo đứt với sợi bông kéo cùng điều kiện. Kết quả chỉ ra rằng xơ khóm pha có độ bền kéo đứt $14,5 \mathrm{cN} /$ tex cao hơn so với sợi bông $100 \%$ cùng loại là $9,3 \mathrm{cN} /$ tex và có thể dệt trên máy dệt kim yêu cầu độ bền sợi $>10 \mathrm{cN} /$ tex. Sợi được dệt thử trên máy dệt kim tròn (máy thí nghiệm) tại Trường đại học Bách Khoa TP. Hồ chí Minh, Khoa cơ khí, bộ môn kỹ thuật dệt may.

Với tiềm năng trong kéo sợi - dệt vải, việc nghiên cứu các yếu tố ảnh hưởng đến quá trình phân tách xơ khóm là cần thiết giúp xơ khóm phân tách tốt hơn, đạt được độ mảnh, độ đều và các tính chất cơ lý cần thiết cho kéo sợi - dệt vải và tạo các sản phẩm may mặc. Nghiên cứu tỷ lệ pha trộn xơ khóm với bông hoặc nghiên cứu dây chuyền kéo sợi chuyên biệt cho xơ khóm là các vấn đề cần được nghiên cứu phát triển. Ngoài ra, để có thể xử lý xơ khóm với quy mô lớn đòi hỏi phải có một thiết bị sơ chế ban đầu giúp loại bỏ phần thịt lá, nâng cao năng suất và hiệu quả phân tách xơ khóm.

\section{TÀI LIỆ THAM KHẢO}

[1] Sisti, L., et al., Retting process as a pretreatment of natural fibers for the development of polymer composites, in Lignocellulosic composite materials. 2018, Springer. p. 97-135.

[2] Franck, R.R., Bast and other Plant fiber. Vol.39.2005:Crc Press 
[3] Ibraheem, S.A., et al., The Effects of Combined Chemical Treatments on the Mechanical Properties of Three Grades of Sisal. BioResources, 2016. 11(4): p. 8968-8980.

[4] Zwane, P.E. and R.M. Cloud, Development of fabric using chemically-treated sisal fibres. 2006.

[5] Mokhtar, M., Characterization and treatments of pineapple leaf fibre thermoplastic composite for construction application. 2007: Universiti Teknologi Malaysia.

[6] Asim, M., et al., A review on pineapple leaves fibre and its composites. International Journal of Polymer Science, 2015.

[7] Jaramillo, N., D. Hoyos, and J.F. Santa, Composites with pineapple-leaf fibers manufactured by layered compression molding. Ingeniería y competitividad, 2016. 18(2): p. 151-162.

[8] Yusof, Y., S.A. Yahya, and A. Adam, Novel technology for sustainable pineapple leaf fibers productions. Procedia CIRP, 2015. 26: p. 756-760.

[9] Niếu, N.H., P.T. Bình, and H. Sáu, Một Số Thay Đổi Về Tính Chất Sợi Dứa Việt Nam Bằng Phương Pháp Xử Lý Trong Dung Dịch Sodium Hydroxide. Science \& Technology. 10(03-2007).

[10] Tri, H.V., Vật liệu may, Nhà xuất bản Đại học Công Nghiệp TP. Hồ Chí Minh, 2016

Ngày nhận bài:12/09/2019

Ngày chấp nhận đăng: 08/01/2020 